\title{
Tess as a Kaleidoscope of Socially Constructed Images in Tess of the D'urbervilles
}

\author{
* Romana Jabeen Bukhari \\ ** Tahira Asgher, Assistant Professor (Corresponding Author) \\ *** Safia Parveen, MS Scholar
}

\begin{abstract}
This study aims to examine the Victorian novel Tess of the D'urbervilles to explore the general social construction of women which prescribes images and roles for them and moulds them accordingly. The researcher selected Thomas Hardy's Tess of the D'Urbervilles, which portrays the plight of women in Victorian England. This qualitative study makes a thorough analysis of the female protagonist who is exploited by the social prescription of her identity and concludes that the female figure is no more than the kaleidoscopic images of hers drawn by others. The study applies the concept of social construction with feministic insight. It hints that women cannot attain full potential until they and society establish their existential rights as empowered and independent human beings. It points out that the resistance against the dominant patriarchal ideologies endows women with a new image and identity, and ensures the possibilities to break away from social prescription.
\end{abstract}

Keywords: Social Construction, Plight, Victorian England, Exploitation, Identity, Resistance, Existential Rights

\section{Introduction}

Social norms set by men have been changing, so are the roles and images of women. Women have no identity other than what men enjoin upon them. De Beauvoir (1956) also contends: "One is not born, but rather becomes a woman" (p, 273), which is her famous oft-quoted remark. Man does not regard a woman as an independent human being. She is defined and recognized in society through him and through whatever label he tags her with.

Woman's role building is an aspect of her exploitation. De Bouvoir remarks, "She is defined and differentiated concerning man and not he about her; she is the incidental, the inessential as opposed to the essential. He is the subject, the absolute -she is the other" (p. 16). She is an object, a thing, a commodity that is given meaning by man. She is an object in the eyes of the subject. Womanhood is a repressive social institution in which her gender and role are socially constructed. The dilemma of women is that they have as many identities as there are their male exploiters. Thus the female body is moulded into different roles and images by society. Tess faces this social prescription and fights for her survival and her identity on so many levels. This study is a discussion on the kinds of social roles and images which are imposed on her by others in society.

\section{Literature Review}

Myriads of literary critics have discussed the character of Tess from different angles. Yang (2009) analyses the character of Tess both as a female and a peasant. He observes that Tess struggles to be recognized as an independent entity but she never gets the chance to. Society erodes her self-esteem and brands her as an unacceptable woman socially, economically and morally (p.114). Tess becomes a victim and a fallen woman according to Victorian standards. Her struggle in fighting against this image and role brings the essential purity of her spirit.

A woman is an object to be looked at. She is defined by the 'look' or particularly male gaze which sets certain criteria as to how she is to look, behave and act which conforms to the norms of patriarchal society. Widowson (2010) observes that Tess is continually presented in terms of how she is 'seen' by others, particularly how she is viewed by Alec and Angel, so much so that she seems to be composed of the images other people make about her (p. 70). He discusses Tess as an object to be looked at. He makes seeing, representation and the pure woman the focal point of his essay.

\footnotetext{
* Romana Jabeen Bukhari Email: rjbs94@yahoo.com

** Department of English Linguistics, Islamia University Bahawalpur, Pakistan Email: tahira.asgher@iub.edu.pk

*** COMSATS University Islamabad, Lahore Campus. Email: safiaaslam375@ gmail.com
} 
The same dilemma of the female body is highlighted by Silverman (1984) who analyses the character of Tess and observes that Tess is a surface upon which a pattern is imposed. Her figure is anchored to a mastering gaze (p.8).

Boumelha (1982) is one of Hardy's significant critics. According to her, it is Tess's sexual attractions that make her a victim of sexual exploitation. Boumelha compares Tess's sexuality with Hardy's other heroines and remarks that it is her exceptional physical nature that evokes erotic responses from men. These responses link her to male images and fantasies (125).

A woman is a bearer of family honour. She is expected to embrace the highest ideals of modesty and morality. Any moral lapse or breach on her part entitles her to severe retribution from physical punishment to societal ostracism. Brady (1999) surveys Hardyan female characters. Commenting on the debate about Tess as a fallen woman, she writes that because Tess was considered physically impure, paradoxically, she was seen to be morally pure. She observes the narrative's focus on the female body. She finds Tess possessing supremely moral traits of humanity and imagination who resists her reduction to a single ideological position (p. 96).

Gregor (1974) has discussed Hardyan characters from two levels of depiction: as a human being and as a tool in the narrative. Regarding the loss of her identity and being labelled as a kept woman, he observes that Tess has lost sense of herself to such an extent that at Sandbourne, Angel realizes that Tess was unable to know the body before him as hers (p. 194).

Tess' tragedy is that she is the victim of a hypocritical society that has dual standards of morality for men and women. Yuan and Rao (2018) have tried to analyse the causes of Tess' tragedy and called it "both a tragedy of love and the tragedy of life. The process of tragedy is the process of various contradictions in the characters and the social environment" (p. 1). They have enumerated the social hypocritical system, capitalistic economy, unjust laws and selfish parents on the one hand and the impact of hypocritical main characters on the other hand which led her to her tragic end.

As a woman is objectified, she can be bartered as an object. Her entity and identity are lost amid the demands and claims society makes on her. West (2016) makes her observation about "portrayals of women-as-animal - and in extension, women-as-property" (p.1), in Tess of the D'Urbervilles and The Mayor of the Casterbridge. She has proved how Tess has been identified with birds and horses and how her oppressor also treats her like an animal to be controlled for his amusement. Even Tess deems herself "as a part of the natural world", (p. 2) when she compares the misery of the dying partridges with her own and finds them more miserable than herself. West concludes that Hardy's writing seems to carry early signs of post-humanism.

Different critics have used different insights to define Tess. The study is significant in the fact that in analysing Tess, it has applied the concept of social construction with feminist insight. It has pointed out the role of society in general which tries to mould women in the light of its desires and requirements. This role and image construction which does not define a woman's true nature and is rather imposed on her is the most oppressive kind of exploitation she can be meted out.

\section{Theoretical Framework}

What our role or identity is, is socially constructed. We know about our identity and the identity of others through interaction with media, institution, organizations and our family and peers. As far as gender is concerned, female roles and images are created by culture and society. In reality, these roles are the reflection of the person's expectations and desires who imposes these roles upon someone and may not represent reality.

Many critics have made observations about the social construction aspect of female identity. Society shapes and moulds women according to their norms and standards. Showalter (1981) remarks that the female psyche is constructed by cultural forces (p. 197). Bordo (1993) comments on this aspect of female objectification and social construction of identity as a politically inscribed entity, which is controlled by society. It ranges from foot binding, through corseting, rape, battering, compulsory heterosexuality, forced sterilization, to unwanted pregnancies (p. 21).

Grosz (1995) finds the female bodies as inscriptive models which are marked, transformed and written upon or constructed... (p.33). Braidotti (1994) also holds the same views regarding the social and cultural significance of the female body. According to her, the female body is culturally coded. It is not a natural entity (p. 238).

In this regard, Butler's concept (1993) of performativity is also relevant. She agrees with de Beauvoir that biological sex does not determine gender, she believes that gender is a choice, and it is 
never fixed per se, but continuously renegotiated. Male-female dualism like female good-heartedness and female emotional maturity are also constructed by society as gender. She believes that women can resist the social norms and that 'gender choice is empowering'. Female social roles are often acted out, that is they are not innate. That is why she calls gender performance, an act that is continuously repeated. To her, it is a ritualized production that is repeated through constraint, prohibition, and the threat of ostracism or death (Butler, 1993, p. 95). Butler's observation is quite enlightening that the female role in society is just a performance and that by resisting social pressures, women can be empowered.

The study tried to find out the answers to these questions in the light of the above observations:

1. What are the different images imposed on Tess?

2. Do these images represent the real Tess?

3. How can women like Tess break away from social prescription and social construction?

\section{Research Methodology}

This study is an analysis of the female protagonist. It is designed on the qualitative pattern in which the extracts from the primary texts were used as data, and secondary sources like critics' books, journals and web sources were utilised to consolidate the thesis stance of the researcher. The sociological term of social construction will be applied with feminist insight as to the perspective. My study assumes that society is patriarchal where superstructures are under male control. Therefore, in patriarchal societies, women are marginalized and consequently socially constructed.

\section{Analysis}

Past portrays a thoroughly different picture when seen through the eyes of women. The way women interacted in society, struggled against the social ideology, resisted the patriarchal and gendered structures and the fact that most women's lives were structured by the ideology and the material reality of family and in this context how they carved out identities for them is part of the history of many centuries. The methods of historical research, objective analysis have brought out the social, cultural and economic change that helped in forming a more accurate picture of the gendered character of the past. Clark (2006) observes:

Both Catholic and protestant churches had tried to impose, or re-impose, a strict sexual morality in the seventeenth century. The counter-reformation catholic church portrayed women as sexual temptresses, with their low-cut gowns and sparkling ornaments. It imposed strict controls over marriage and viewed sexual desire as the ultimate sin (p. 59).

Besides other aspects, the Victorian society of the nineteenth century was prominent for its two most sensitive areas; its changing ideas of social classes in Victorian England and the issue of the poor condition of the low-class women. On the social level, Victorian society is a male chauvinistic society where male hold the key positions in the social and political institutions and formulate social and moral laws to control the lives of women and children. In this setup, women are compelled to accept whatever role or status and position they are assigned by men. This total dependence and subjugation lead to double standards of morality in a society that best suit the male majority.

The female body is moulded into different roles and images by society. Tess faces this social prescription and fights for her survival and her identity on so many levels. Following is a discussion on the kind of society she lived in and how she is perceived by others in society.

Tess' sexual objectification was initiated by her mother when she asks her "dressing up more the dand" and "to put your best side outward" (Hardy, p. 89). to please her parents, Tess puts herself in her mothers' hands, saying, "Do what you like with me, mother" (Hardy, p. 89). Mrs Durbeyfields is very happy at this "tractability" of her daughter. This being who is half child and half-woman is labelled with an identity (of being a full-fledged woman) and thrust into the cruel world of male chauvinism and egoism to show off the best side of Durbeyfields. Silverman (1984) observes that early in the novel she is presented as a canvas upon which the image of a voluptuous woman is painted by her mother to ensnare the rich young man Alec (p. 8). Her mother is so much delighted at her daughter's appearance that she steps back " like a painter from his easel and surveys her work as a whole" (Hardy, pp. 89-90).

Right in the terms used by de Beauvoir (1956) that a woman is for a man just a sex object and nothing else (p. 16), from her first encounter with Alec, Tess is perceived by Alec as a sexual object and nothing else and all his pursuit of Tess is governed by this perception. His experienced gaze sizes her up as a prospective victim. Though Tess wants to return as soon as possible he pressingly 
conducts her to the lawns, flower beds and fruit gardens where he offers her strawberries. He selects particularly the fine product of the British queen variety and offered to feed her with his own hands. Despite her refusal, "he insisted: and in a slight distress, she parted her lips and took it in" (Hardy, p. 81). And when the two pass by the rose plants, he gave her blossoms to put in her bosom and then "he tucked a bud or two into her hat and heaped her basket with others in the prodigality of his bounty" (Hardy, p. 81). His covetous male gaze is riveted on her behind the blue narcotic haze observing her fullness of growth" (p. 82) when she speaks and even when she eats. From this moment onwards, Alec follows her like a nefarious shadow whether she is whistling to the fowls or trying to catch them in Mrs D'Uerbervilles bedrooms, he is a felt and feared presence for her. For him, she is Ishtar, the goddess of love, fertility and sexuality. Brick (1962) compares Alec to the Serpent and Tess to Eve who is easily seduced because of her desire for social mobility, commenting that as serpent springs into Eve's consciousness, so does Alec into Tess's (p 118). But as time passes, Alec tries to dominate her by depriving her of her pride in nobility and beauty and shape her into compliance with his desire. The episode in the Chase is clear evidence of how he divests her of her own will when despite her rejection of his offer to take her back to Trantridge, she finally finds herself seated with him on his horse. Tess' victimization as a sexual object stigmatizes her forever with an image which she cannot get rid of, however much she may desire to. Now she is a fallen woman in the eyes of the world. Silverman (1984) remarks on Tess' fallenness that this is the most ineradicable inscription which occurs in the Chase. He makes a comparison between Tess and her father concluding that whereas John Durbeyfield is presented as having a stable and knowable appearance, his daughter has no visual consistency as she is painted, imprinted and patterned so that she may be seen (p. 9).

As rape was not considered a crime against a woman, but a crime against father or husband (Clark, p.60), so Tess incurs the guilt of the mishap. She suffers from "an irremediable grief at her weakness in the mind of some ethical being" (Hardy, p. 135), but all the others in this patriarchal society including Alec himself are exempt from any blame. Humma (1989) reiterates Bricks' idea of Alec when she also compares Alec to Serpent and adds that it is perfectly consonant with Tess's experience that Alec stands for the serpent and the social world of man (p. 66)

Tess as a fallen woman suffers alone while society, on the whole, is insensible to her sufferings. Joan Durbeyfield is vexed at the frustration of her dreams about the possible marriage between Tess and Alec and bewails that Tess never thinks of doing some good for the family rather she thinks only for herself. She cannot fathom the depth of moral qualms Tess is undergoing. Butler (1978) points out that Tess is agonized by moral qualms as she has committed adultery about which each Christian should feel guilty (p. 115). Thus society is concerned about its petty gains and nobody bothers how Tess is suffering on so many levels.

Williams (1993) comments that modern society is diseased, cruel, and inhuman and the conventions it imposes are unnatural. According to him, Tess has not broken any natural law. She is made to break an accepted social law. The cause of her tragedy is the clash between natural human feelings and social norms. This is the very conflict that is acted out in the mind of the man she loves i.e. Angel Clare (p. 96). In one respect, Angel aligns with Joan Durbeyfield as both feel Tess has frustrated their expectations of her. Joan thinks that Tess has not played her trump card (her beauty) well whereas Angel feels that she has played foul with her. The romantic idealist that Angel is always seen as Tess as she is not. For him, she is a virginal child of nature "a visionary essence of woman - a whole sex condensed into one typical form. He called her Artemis, Demeter, and other fanciful names half teasingly, which she did not like because she did not understand them" (Hardy, p. 187). Higonnet (1993) remarks that Angel visualizes her in the form of stereotyped femininity. When he calls her Demeter or Artemis, she asks him to call her Tess. His limited experience with women-led him to think that her 'no' meant 'yes', that her negative meant nothing more than the affirmative. He patronizingly interprets her self-suppression as if he were construing a text (p. 18). He was hardly aware that she wanted him to see her as she truly was.

For Angel, Tess is innocence and purity incarnated. He wraps her in different images but the real Tess is always obscured under them. Sometimes she is the image of a goddess and at other time she has nothing ethereal about her. She is a woman of flesh and blood. With real warmth, real vitality and real incarnation. His male gaze which is sizing her up like that of Alec but with a different perspective makes Tess conscious all the times that she is being observed. 
On her wedding night after her confession, Artemis or Demeter is pulled down from her high pedestal and reduced to "an unapprehended peasant woman" (Hardy, p. 302). Hazen (1977) defends Angel Clare on the ground that Angel's failure is the result of Tess' own failure to reveal her past to him before marriage. He contends that her shocking story of the liaison with Alec and the birth and death of a child could upset any man (p. 132). His very defence of Angel is enough to prove that for him, she would never be the woman that she was. For him she was one person, now she is another. He ruthlessly proclaims, "The woman I have been loving is not you" and Tess realizes that "he looked upon her as a species of an imposter: a guilty woman in the guise of an innocent one" (Hardy. p. 299). It was another woman he loved in her shape, "but not the same. No, not the same" (Hardy, p. 302) as Angel repeats. Yahya (2017) observes that Angel considers her a fallen woman as he becomes judgemental about her character in the light of the moral norms which he has been fed upon. He cannot ignore the social customs and conventionality (p. 35). Peck (1987) views this as a conflict between the natural love of the two lovers and the social attitudes which make Tess a fallen woman in the angel's eyes. He concludes that "Angel's social prejudices are stronger than his natural feelings" (p. 51). Brick (1962) calls the angel's renunciation of Tess 'his ideological rape of Tess'" (p. 129). Avila (2017) maintains that this scene "...contributes to deteriorating the image of mercy and compassion that this male personage has at the beginning of the novel (p.14).

Tess's body is inscribed with the label of a fallen woman. Tess, as the analysis of her life proves, is not a fallen woman, rather she is a victim of circumstances. Tess is ruined by two men in her life. Both of them want to fashion her in the image of their desire. If on the one hand, Tess is eclipsed by the sinister shadow of the serpent-like Alec, on the other hand, she is suffocated by the exalted idealism of Angel.

When we compare Tess with her male counterparts, we see her morally much exalted above them. The nefarious serpentine Alec after his temporary conversion to an evangelist tries to put the whole blame of his wicked nature on Tess. Alec asks Tess not to tempt him "by your charms or ways" (Hardy, p. 390). For him she is a "temptress, a dear damned witch of Babylon" (p. 402) for both Alec and Angel, she is an object of desire, a temptress and imposter whose 'prestidigitation' is pointed out by Angel, but the fact is that Tess is the victim of both men, violated by Alec and renounced by her husband. Alec equates her with the other country girls he has victimized by implicating her in a sexual relationship, whereas Angel weaves her into his romantic and idealistic patterns of mythology. And when he comes to know of her past, he deserts her to face the cruel world alone. Kaur's (2005) observations about the purity of Tess are very relevant. She observes that Hardy challenged and violated Victorian social conventions which believed in the irretrievable virtue of women by calling Tess a pure woman. In Hardy's eyes, she is not dishonoured by her fall. To him, she has not committed this lapse like a coquette. As she is morally pure, her social lapse is of no importance (p. 100).

MacCabe (2014) observes that Tess is destroyed by the Victorian double standards which required virginity in a woman as a condition of marriage but allowed a man his visits to the brothel. Angel who comes from a family of men with an ecclesiastic background, suffers from manly pride and self-importance. He cannot forgive Tess for her moral aberration but he forgets that he has a sexual episode in his life which Tess has very generously forgiven. Angel's exploitation of Tess is all the more culpable as he does so in the name of high morals. Brick (1962) observes that Alec is a melodramatic villain but Angel who first appears to be his foil, the hero, is equally stock and as Alec's peer for effective Satanism, "all the more wicked for his rationalization of villainy as goodness. For as Angel's direct ideological assault upon Tess surpasses Alec's mere rakish seduction, so are her sufferings from the childbirth, unknown to Alec, surpassed by those from the enslavement brought upon her by Angel's prolonged absence " (p. 129).

Angel's apparent prudishness is as oppressive for Tess as Alec's erotic pursuance. Mallett (2004) observes that Angel assumed that the woman he loved must be a virgin, not an unmarried mother (p.90). This priggish idealist after his moral chastisement of Tess offers Izzy Huett to accompany him to Brazil as his mistress. So the main reason behind his rejection of Tess is not his prudish morality but his male ego. Silverman (1984) notes that Angel is upset by the disclosure that she had a relationship with another man. He refuses any possible association between Alec's erotic construction of Tess and his image of her and drives a wedge between past and present (p.14). Phelps (1909) observes about Henry Knight and Angel Clare who are certainly not villains, each could not 
have treated the woman who loved him with more heartlessness even if each had been a deliberate villain. (p.511). Watson (2005) also mentions worse anger of readers against this intellectual, man (Angel) than they could have against the wicked and heartless libertine (Alec) (p. 215).

Miller (1970) observes that Tess is never really free after her seduction by Alec (p. 102). Referring to the May-Day dance scene, the strawberry scene and the fieldwork scene, Sadoff (1993) observes how Tess is looked at by others, "Thus the narrator observes Tess as a 'spectacle' drawing the successive gazes of others, whether in approbation, examination or moral inspection. Her 'looks' figuratively entice him to 'look'. The relay of looks directed at Tess constitutes the female figure as sexually arousing, unknowingly on display ..." (p. 151).

We find that the history of Tess is no more than the kaleidoscopic images of her drawn by others. The white-clad woman - child of May dance, the kept woman of Alec, the virginal daughter of nature viewed by Angel at Talbothays, the goddess of Angel's dreams, the fallen woman of his frustrated idealism, or the fashionable woman in a gown at Sandbourne - all are the different concocted images in the haze of which, it is difficult to trace the true Tess. None of these images represents the real Tess. They are so opposed to one another that it is illogical to think that any of them can define Tess. Widowson (2010) refers to John Goode who notes the objectification of Tess by the narrator, particularly by making her the object of consumption of both Alec and Angel, and the effect is to make the voyeuristic readers the subject of her and thus guilty of the object images which she is to contradict (p. 75). He observes that Tess is an amalgam of images of her as perceived by individuals or by society. She has no character of her at all. Tess is what the others and especially the author constructs her to be (p.84). The analysis amply proves that all through her life, Tess has been shaped, reshaped and defined by people around her. She has never virtually enjoyed a free independent and autonomous self. It is her exploiters who have reduced her to the particular image and role which best suits them.

\section{Conclusions}

The worst kind of exploitation is to snatch a woman's identity and to label her with a socially constructed identity. History of Tess proves that a woman has as many identities as there are men or their whims she comes across. Women are stereotyped by men the way they want to mould them. Consequently, women are labelled with different tags. Images such as witch, sorceress, fallen woman, lost women, and the holy woman is associated with women only. No such tagging is linked with the male figure.

The exploitation of women can be stopped only if society changes its norms that are discriminatory against women. Bauer (2001) notes that at the end of The Second Sex, de Beauvoir suggests that social revolution is the one and the only one of the prerequisites to improve women's and men's situation. Unless the moral, cultural and social consequences are brought about, the new woman cannot appear (p. 279). The above discussion proves how women have been framed and moulded into the roles and images which are dictated by society. None of these social prescriptions defines the inner nature of the woman who is victimized. The real woman lies hidden somewhere else.

\section{References}

Avila, J. G. (2017). Self-sacrifice vs self-preservation in Tess of the D'Urbervilles. Dissertation. Universitat Jaume .1. http://repositori.uji.es/xmlui/bitstream/10234/168676/1/TFG_2017_ GarciaAvilaJessica.pdf

Bauer, N. (2001). Simone de Beauvoire: Philosophy and feminism. New York: Columbia.

Bordo, S. (1993). Unbearable weight: Feminism, western culture and the body. London: California.

Boumelha, P. (1982). Thomas Hardy and women: Sexual ideology and narrative form. Sussex: The Harvester Press, 1982. http://digital.library.adelaide.edu.au/dspace/handle/2440/ 45124. [15 June 2016].

Brady, K. (1999). 'Thomas Hardy and the matters of gender'. In D. Kramer (Ed.), The Cambridge Companion to Thomas Hardy (pp. 93-111). https://livreordie.files.wordpress.com/.../Thomashardy-and-matters-of-gender.p...

Braidotti, R. (1994). Embodiment and sexual difference in contemporary feminist theory. New York: Columbia.

Brick, A. (1962). 'Paradise and consciousness in Hardy's Tess'. Nineteenth-Century Fiction, 17(2), $115-13$.

Butler, J. (1993). Bodies that matter. New York: Routledge. 
Butler, L. S. J. (1978). Thomas Hardy. New York: Cambridge.

Clark, A. (2006). 'Female sexuality'. In D. Simonton. (Ed.), The Routledge History of Women in Europe Since 1700 (pp. 54-92).New York: Routledge.

De Beauvoir, S (1956). The second sex H.M. Parshley (Ed. \& Trans.). London: Jonathan Cape.

Gregor, I. (1974). The great web: The form of Hardy's major fiction. Michigan: Rowman \& Littlefield.

Grosz, E. (1995). Space, time and perversion: essays on the politics of bodies. New York: Routledge.

Hardy, T. (1978). Tess of the D'Urbervilles: A pure woman. London: Penguin.

Hazen, J. (1977). 'Angel's Hellenism in Tess of the D'Urbervilles'. College Literature, 4(2), 129-135.

Higonnet, M. R. (Ed.). (1993). 'A woman's story: Tess and the problem of voice'. In M. R. Higonnet (Ed.) The Sense of Sex: The Feminist Perspective on Hardy (pp. 14-31). USA: Illinois.

Humma, J. B. (1989). 'Association language and disguise: The imagery of nature and sex in 'Tess'. South Atlantic Review. 54(4), 63-83. JSTOR. Web. [23 Sep. 2016].

Kaur, M. (2005). The feminist sensibility in the novels of Thomas Hardy. New Delhi: Sarup.

MacCabe, C. (2014). 'The truest Tess'. The Criterion Collection. <www.criterion.com /current/posts/3076-the-truest-tess. [12 May 2016].

Mallet, P. (2004). 'The immortal puzzle': Hardy and sexuality'. In P. Mallett (Ed.) Palgrave Advances in Thomas Hardy Studies (pp. 181-202). London: Palgrave Macmillan.

Miller, H. J. (1970). Thomas Hardy: Distance and desire. Massachusetts: Harvard.

Peck, J. (1987). How to study a Thomas Hardy novel. London: Macmillan.

Phelps, W. L. (1909). 'The novels of Thomas Hardy'. The North American Review. 190(647), 502514. [24 Sep 2016]

Sadoff, D. F. (1993). 'Looking at Tess: The female figure in the two narratives. In M. R. Higonnet Ed.), The sense of sex: The Feminist perspective on Hardy (pp. 149-172). USA: Illinois.

Showalter, E. (1981). Feminist criticism in the wilderness. Critical Inquiry. 8(2), 179-205. JSTOR. Web. [25 June 2016].

Silverman, K. (1984). 'History, figuration and female subjectivity in Tess of the D'Urbervilles'. Novel: A Forum on Fiction. 18(1), 5-28.

Watson, W. (2005). 'Review of Tess of the D'Urbervilles'. In R. G. Cox (Ed.), Thomas Hardy: The Critical Heritage (pp. 213-218). London: Routledge.

West, A. (2016). 'Posthumanist Hardy? Rethinking "the Whole Conscious World Collectively", FATHOM [12 April 2018]. http://journals.openedition.org/fathom/651; DOI: 10.4000/ fathom.651

Widowson, P. (2010). 'Moments of vision: Post modernizing Tess of the D'Urbervilles'. In H. Bloom (Ed.), Critical Views: Thomas Hardy (pp. 69-88). New York: Bloom's Literary Criticism.

Williams, M. (1993). A preface to Hardy. New York: Longman.

Yuan, P. Y and Rao, Y. (2018). 'An analysis of the tragedy of Tess of the D'Urbervilles'. English Language Teaching. 11(7), 71-75. Web. [12 August 2018].

Yahya, Y. H. I. (2017). 'Analyzing the conflict in Thomas Hardy's novel, 'Tess of the D'Urbervilles". Dissertation. Sudan University of Science and Technology, College of Graduate Studies. http://repository.sustech.edu/handle/123456789/18380

Yang, W. (2009). 'Analyzing exertion of Hardy's tragic effect in Tess'. International Education Studies. 2(1), 112-115. Web. [4 August 2016]. 